\title{
Comparative analysis of the use of data marts in two different manufacturing organizations
}

\author{
S.R. Ponelis \\ Department of Information Science \\ University of Pretoria \\ J.J. Britz ${ }^{*}$ \\ Department of Information Science \\ University of Pretoria \\ britzh@postino.up.ac.za
}

\section{Contents}

1. Introduction and statement of problem

2. Data marts as management information delivery mechanisms

3. Use of data marts in manufacturing organizations with third-party distribution

4. Case study of pharmaceuticals industry

5. Comparative analysis

6. Conclusion

7. References

\section{Introduction and statement of problem}

Organizations that manufacture products that are physically distributed to customers and consumers by a third-party distributor are faced with a problem regarding the distribution data. The distribution data are captured by the third-party distributor or distributors during the distribution process and include, for example, the invoiced transaction details, customer details, inventory levels and outstanding orders. Manufacturers need this data to optimize their distribution channels, to understand the demand in the marketplace and to offer their customers quality service by better understanding and responding to their requirements.

Third-party distributor or distributors will normally make this data available to the manufacturer. The manufacturer then has to meet its own management information requirements, that is, making this data internally accessible to support and optimize decision making regarding sales and marketing functions as well as other related aspects such as production. Manufacturers must determine how best to meet this management information need. There are many mechanisms or types of information systems that can be used to deliver management information in organizations. One possibility is the use of a data 
warehousing approach, in particular the use of data marts.

The central problem statement of this research took the form of a hypothesis that was tested by means of evidence presented, namely that there was no significant difference in the use of sales and marketing data marts as management information delivery mechanisms in manufacturing organizations in different industries, particularly in pharmaceutical and branded consumer products.

\section{Data marts as management information delivery mechanisms}

Data warehouses and data marts deliver management information to users by means of different access tools. Table 1 contains a comparison of the different classes of data mart access tools found in the literature together with the consolidation of these classifications for the purpose of this research.

Table 1 Comparison of classes of data mart access tools with consolidation

\begin{tabular}{|c|c|c|c|c|}
\hline $\begin{array}{l}\text { Gray and } \\
\text { Watson } \\
\text { (1998:123) } \\
\end{array}$ & $\begin{array}{l}\text { Berson and } \\
\text { Smith } \\
(1997: 223)\end{array}$ & $\begin{array}{l}\text { Tanler } \\
(1997: 95)\end{array}$ & $\begin{array}{l}\text { Poe (1998: } \\
\text { 233-234) }\end{array}$ & $\begin{array}{l}\begin{array}{l}\text { Consolidation } \\
\text { of } \\
\text { classifications }\end{array} \\
\end{array}$ \\
\hline Queries & Reporting & \multirow[t]{3}{*}{$\begin{array}{l}\text { Query and } \\
\text { reporting }\end{array}$} & \begin{tabular}{|l|} 
Data access and \\
query tools
\end{tabular} & \multirow[t]{3}{*}{$\begin{array}{l}\text { Query and } \\
\text { reporting }\end{array}$} \\
\hline $\begin{array}{l}\text { Managed query } \\
\text { environments }\end{array}$ & Managed query & & Report writers & \\
\hline $\begin{array}{l}\text { Executive } \\
\text { information } \\
\text { systems (EIS) }\end{array}$ & $\begin{array}{l}\text { Executive } \\
\text { information } \\
\text { systems }\end{array}$ & & $\begin{array}{l}\text { Executive } \\
\text { information } \\
\text { systems }\end{array}$ & \\
\hline \multirow[t]{2}{*}{$\begin{array}{l}\text { Decision } \\
\text { support systems }\end{array}$} & \multirow[t]{2}{*}{$\begin{array}{l}\text { On-line } \\
\text { analytical } \\
\text { processing }\end{array}$} & \multirow[t]{2}{*}{$\begin{array}{l}\text { Multi- } \\
\text { dimensional } \\
\text { analysis }\end{array}$} & $\begin{array}{l}\text { Multi- } \\
\text { dimensional } \\
\text { database } \\
\text { management } \\
\text { systems }\end{array}$ & \multirow[t]{2}{*}{$\begin{array}{l}\text { On-line } \\
\text { analytical } \\
\text { processing } \\
\text { (Olap) }\end{array}$} \\
\hline & & & $\begin{array}{l}\text { Advanced } \\
\text { decision } \\
\text { support tools }\end{array}$ & \\
\hline \multirow[t]{2}{*}{ Data mining } & \multirow[t]{2}{*}{ Data mining } & $\begin{array}{l}\text { Data mining } \\
\text { (agent } \\
\text { processing) } \\
\end{array}$ & & \multirow[t]{2}{*}{ Data mining } \\
\hline & & $\begin{array}{l}\text { Statistical } \\
\text { analysis (user- } \\
\text { directed) }\end{array}$ & & \\
\hline
\end{tabular}

Swift (2000) discusses the evolutionary use of a data warehouse or data mart. This use progresses through three stages, starting with reporting. Even reporting from the data warehouse to determine what happened, mostly through predefined queries, 'provides new views and an ability to use combined, cross-organizational detailed data to understand the past' (Swift 2000). The second stage of use is characterized by analysis focusing on reasons for what happened. The final and most sophisticated stage, also presenting the most competitive advantage, is predicting what will happen by means of analytical techniques. These stages are summarized and mapped against the different classes of access tools in 
Table 2.

Table 2 Mapping of stages of data mart use (Swift 2000) against class of access tool

\begin{tabular}{|l|l|l|l|}
\hline Stage of use & Reporting & Analysis & Prediction \\
\hline Class of access tool & $\begin{array}{l}\text { Query and } \\
\text { reporting }\end{array}$ & Olap & Data mining \\
\hline
\end{tabular}

Reporting and analysis both seek to answer questions that are historical or focused on the past, whereas prediction is focused on the future. This distinction in focus can be formulated more precisely: deductive tools support the 'process of applying specific - though probably ad hoc - questions against the available data' (3Com 2001:38), whereas inductive tools support the 'process of interrogating the available data before a specific questions has been formulated' (3Com 2001:39). Therefore, reporting and analysis using query and reporting and on-line analytical processing (Olap) tools are deductive in nature, whereas prediction that uses data mining tools is inductive. This is summarized in Table 3.

Table 3 Categories of end-user application classifications

\begin{tabular}{|l|l|}
\hline Deductive & Query and reporting \\
\cline { 2 - 2 } & Olap \\
\hline Inductive & Data mining \\
\hline
\end{tabular}

The natural progression from reporting to analysis to prediction normally takes place over time. One would expect that the simplest needs, namely reporting needs, would be satisfied first before progressing to analytical needs and, again, satisfying analytical needs before progressing to predictive needs.

\section{Use of data marts in manufacturing organizations with third-party distribution}

Two medium-sized manufacturing organizations developed data marts for a very similar purpose, namely to integrate and make accessible management information to managers based on data received from third-party distributors. The first case study is a data mart implementation for a fast moving consumer goods (FMCG) organization with specifically branded consumer goods and the second case study covers a data mart implementation for a pharmaceutical organization.

\subsection{Case study of the branded consumer products (BCP) industry}

The BCP industry encompasses a wide variety of organizations that compete intensely in a number of segments. The organizations in this industry distinguish themselves from other manufacturers of consumer goods by their ability to obtain premium pricing for their branded products, hence the name branded consumer products. To be successful, BCP organizations must perform well at managing their brand and understanding their market and customers.

\subsection{Managing the brand}

Most of the leading organizations in this industry believe that the best way to sustain profitable growth is to maintain a portfolio of exceptional brand name products. Brands are built over time through advertising and promotion. In a study of premium brands, Vishwanath and Mark (1997:123) found that market share alone does not account for the profitability of a brand. Instead 'a brand's profitability is driven by both market share and the 
nature of the category ... if a category is composed largely of premium brands, then most of the brands in the category are - or should be - profitable' (Vishwanath and Mark 1997:124). However, if the category consists mostly of value and private-label brands, then generally lower returns can be expected.

\subsection{Understanding the market and customers}

While many BCP manufacturers face similar challenges associated with managing their brand and understanding their consumers, their retail customers drive many of the most critical issues that these organizations must contend with. As retailers consolidate, develop and disappear, BCP manufacturers are required to continually cater to the demands of the increasingly powerful retailer customers (Vivier 2001; Davenport, Harris and Kohli 2001:64-65). Manufacturers are under intense pressure to execute precisely according to retailer requests or risk back charges and loss of prime shelf space.

Marketing to the retail and distributive trades, that is, the promotion of products to sellers of products as opposed to the actual consumers of products, is called trade marketing. Spending on trade marketing continues to increase and manufacturers are frustrated by the inability to measure and manage its effective use. Manufacturers are trying to understand account-level profitability to ensure that trade spending is used effectively. The implementation of promotional management applications will allow organizations to 'regain control of these [promotional] activities and maximize the return on trade spending' (Brooke and MacTavish 2001).

\subsection{Context of the branded consumer products organization}

During the research, a listed South African-based BCP organization with several subsidiaries, one of which manufacture packaged foods that require refrigerated storage, was investigated. The manufacturer had an agreement with a third-party distributor, which provided chilled and frozen storage from 13 national depots to warehouse and distribute finished goods. The organization's major customer group was retailers, for example supermarkets, hypermarkets and convenience stores. Retailers obtained products either:

- through the third party distributor; or

- direct procurement from the organization's factory premises.

This flow of products from the BCP manufacturer down the supply chain is illustrated in Figure 1.

Figure 1 Flow of products from the BCP manufacturer

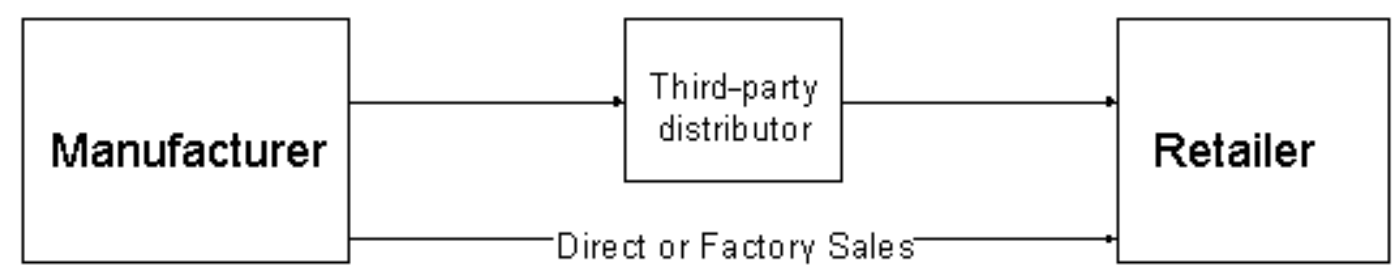

Orders were entered on the manufacturer's system after which orders were uploaded onto the distributor's system. Direct factory sales to customers without any involvement from the distributor were also recorded in the manufacturer system. The distributor was responsible for:

- warehousing finished goods in chilled depots;

- performing physical distribution;

- producing invoices, goods received notes; and 
- maintaining master data for customers and products, together with pricing data.

The organization intended to expand the selected solution to include other strategic business units in the sales and marketing functional area and to expand to other functional areas. Given this requirement, the decision was made to build an independent data mart with a focus on the sales and marketing functional area, which was to be the first in a series of interdependent data marts, which would then result in a distributed data warehouse.

\subsection{Requirements of a sales and marketing data mart solution}

\subsubsection{User community}

The user community for the sales and marketing data mart consisted of members of senior and middle management. These positions, together with corresponding non-exhaustive lists of the primary responsibilities of each position that particularly require sales and marketingrelated management information, are listed in Table 4.

Table 4 Principal responsibilities by position in the BCP manufacturing organization

\begin{tabular}{|c|c|}
\hline Position & Principal responsibilities, including but not limited to: \\
\hline Financial director & $\begin{array}{l}\text { - Design, develop and implement the financial strategy } \\
\text { - Report and analyse the financial results } \\
\text { - Provide insight and recommendations to the managing } \\
\text { director }\end{array}$ \\
\hline $\begin{array}{l}\text { Sales and marketing } \\
\text { director }\end{array}$ & $\begin{array}{l}\text { - Evaluate market trends to develop strategies to improve } \\
\text { the organization's position in the marketplace } \\
\text { - Generate forecasts and develop overall product } \\
\text { strategies to maximize market share and the profit and } \\
\text { loss position } \\
\text { - Deliver sales results to meet budgeted targets } \\
\text { - Along with the financial director, devise the annual and } \\
\text { quarterly compensation programmes for the sales force }\end{array}$ \\
\hline $\begin{array}{l}\text { Regional sales } \\
\text { managers }\end{array}$ & $\begin{array}{l}\text { - Analyse regional market penetration and travel logistics } \\
\text { and implement programmes to achieve optimal territory } \\
\text { coverage } \\
\text { - Coordinate and monitor sales representative pull- } \\
\text { through among targeted providers } \\
\text { - Provide accurate forecasts to the sales and marketing } \\
\text { director of predicted revenue levels }\end{array}$ \\
\hline $\begin{array}{l}\text { National account } \\
\text { managers }\end{array}$ & $\begin{array}{l}\text { - Meet and/or exceed sales goals for assigned regional } \\
\text { - Manage the relationship with key suppliers }\end{array}$ \\
\hline
\end{tabular}

\subsubsection{Management information requirements}

To fulfil the responsibilities listed in Table 4, which primarily focuses on decision making and assessment of performance, accurate management information is required. Based on interviews conducted with the senior members of the user community, the minimum user acceptance requirement for the sales and marketing data mart was the replication of the existing standard management reports. These reports were:

- Daily sales report by customer, product, and region

- Trade marketing spend versus sales by major customer

- Sales by region and product

- Customer ranking by value and volume

- Channel distribution analysis (direct or factory sales versus normal sales, that is, through the third-party distributor) 
- Invoiced sales versus returns (credit notes) analysis

- Product promotions, including location-targeted sales promotions planning

- Retailer pricing and promotional reviews

- Rebates analysis

- Profitability analysis, both for customers and products

- Stock on hand by depot.

These reports align with the factors discussed earlier as necessary for success in the marketplace today. Although these reports are standard management reports, manipulation in personal computer-based spreadsheets was required after extraction from the reporting system to produce them. Additional data were captured manually and year-to-date totals calculated together with formatting according to user specifications.

\subsubsection{Data mart access tool requirements}

Based on the management information reporting requirements, the data mart access tool requirement scan was determined. This is detailed in Table 5.

Table 5 BCP manufacture's data mart access tool requirements

\begin{tabular}{|l|l|l|l|}
\hline $\begin{array}{l}\text { Management } \\
\text { information } \\
\text { requirement }\end{array}$ & Stage of use & Nature & $\begin{array}{l}\text { Data mart access } \\
\text { tool }\end{array}$ \\
\hline Daily sales & Reporting & Deductive & Query and reporting \\
\hline Sales and marketing & Reporting & Deductive & Query and reporting \\
\hline Trade marketing & Reporting & Deductive & Query and reporting \\
\hline Sales by region & Reporting & Deductive & Query and reporting \\
\hline $\begin{array}{l}\text { Sales by product } \\
\text { and by region }\end{array}$ & Reporting & Deductive & Query and reporting \\
\hline $\begin{array}{l}\text { Ranking of top } 30 \\
\text { customers }\end{array}$ & Reporting & Deductive & Query and reporting \\
\hline $\begin{array}{l}\text { Direct versus } \\
\text { normal sales }\end{array}$ & Reporting & Deductive & Query and reporting \\
\hline Sales versus returns & Reporting & Deductive & Query and reporting \\
\hline Promotional review & Reporting & Deductive & Query and reporting \\
\hline Rebates & Reporting & Deductive & Query and reporting \\
\hline $\begin{array}{l}\text { Customer } \\
\text { profitability }\end{array}$ & Reporting & Deductive & Query and reporting \\
\hline $\begin{array}{l}\text { Product } \\
\text { profitability }\end{array}$ & Reporting & Deductive & Query and reporting \\
\hline
\end{tabular}

\subsubsection{Sources of data}

Based on the management information requirements, the sources of data to be used to populate the data mart were determined. Internal sources of data were:

- Budgets, created and stored in spreadsheet format

- Pricing data

- Orders

The external source of the data, which was the distributor, allowed the BCP manufacturer to transfer the following data as separate flat files from their operational systems: 
1. Invoices issued on the previous day

2. Customer master data of additions and modifications

3. Product master data of additions and modifications

4. Stock levels in the respective depots

5. Distributor channels

6. Distributor customer groupings

7. Audit or balancing figures of cumulative daily sales balances.

Files 1, 2, 3 and 4 were used to populate the data mart. The balancing report was used to ensure correct upload of data into the database. The manufacturer wanted to capture additional data particular to its operations on both the customer and product master data. This required a custom-developed application. The volume of sales transactions was approximately 600 to 800 transactions per day. The distributor-related files were not used, as these are specific to the third party distributors system. Although it is not common practice, the manufacturer did not match or reconcile orders and invoices and/or credit notes; as a result the data mart did not use or supply data to the internal operational financial system.

Given the sources and requirements of the data mart, the flow of data to deliver management information through a data mart is depicted in Figure 2.

\section{Figure 2 Data flow surrounding the data mart in the BCP case study}

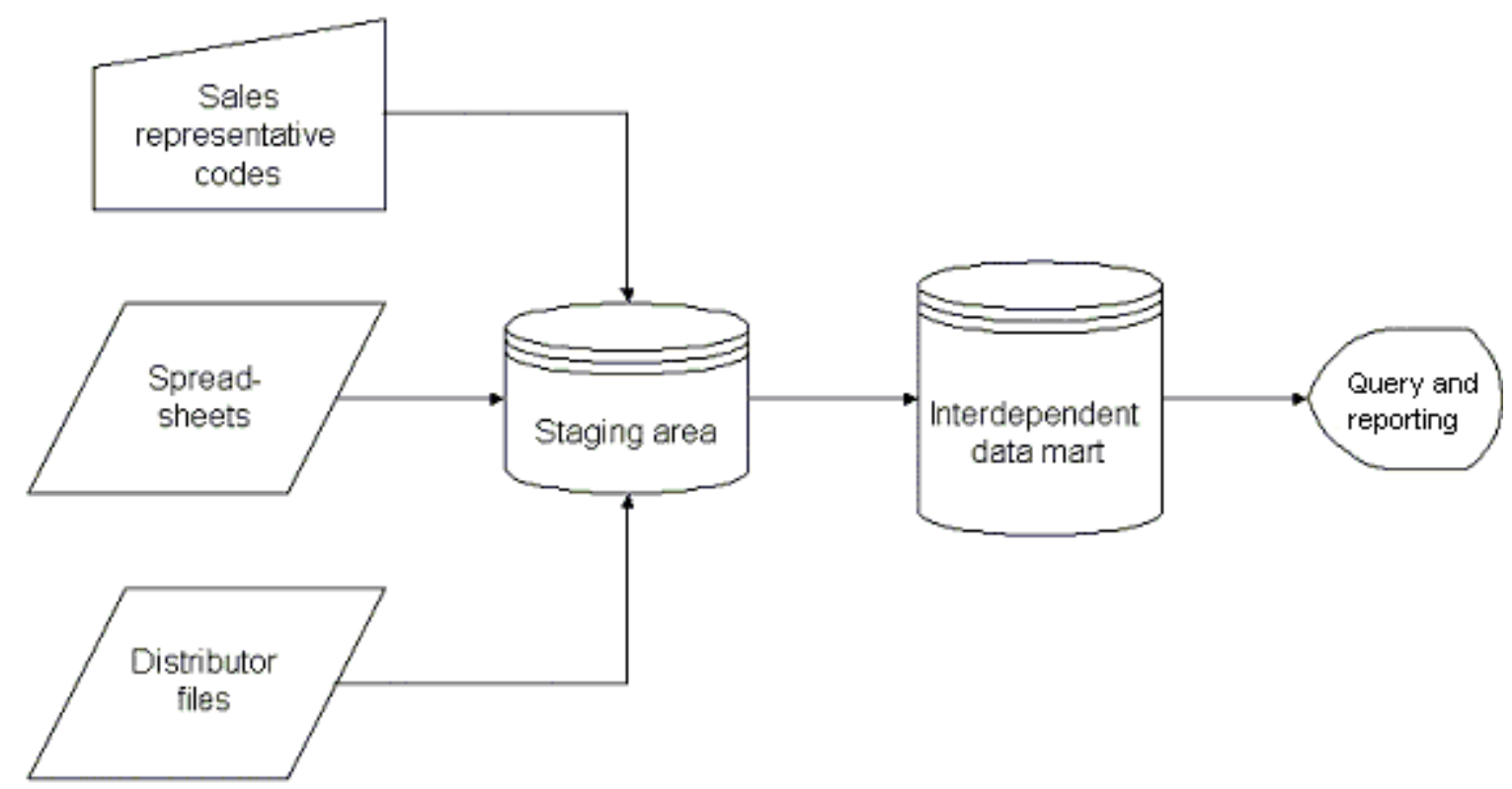

\subsection{Assessment of the use of the sales and marketing data mart}

The assessment of the sales and marketing data mart after completion of the implementation as a management information delivery mechanism indicated that it led to significant improvements in the manufacturing organization. Previously, users had to request management information from a single person with access to a legacy system, which presented a significant bottleneck, as it was a time-consuming process to communicate requirements and then time consuming to produce ad hoc reports. This was eliminated with users preparing their own reports when required, allowing more flexibility. However, users required significant training to become accustomed to using the system themselves to meet their information requirements.

The system helped to improve information flow in the organization. The BCP manufacturer was able to increase its sales through improved targeted trade marketing and monitoring of the outcome. Sales improved as well as forecasting accuracy, and sales representatives were 
better prepared for sales visits.

top

\section{Case study of the pharmaceutical industry}

The standard definition of the pharmaceutical industry is the manufacture of medication used to affect the body chemistry of both humans and animals. In practice, a wider definition includes, among other things the following relevant areas (SSA 2000):

- Ethical pharmaceuticals, which is named medication based on chemical or biological technology that addresses a specific disease under patent. These drugs are normally prescribed by a doctor and are know as prescription-only medicines (PoMs).

- Generic medication, which is medication with expired patents. These are chemically identical substances, for example, penicillin, made by a variety of producers. These drugs are generally also PoMs.

- Over-the-counter (OTC) medication, which often starts as ethical pharmaceuticals. Over time they become recognized as safe for self-medication, for example, aspirin.

\subsection{Business issues currently facing pharmaceutical organizations}

Pharmaceutical organizations are engaged in the discovery, development, manufacture, distribution and sales of the products listed above or others not included. The pharmaceutical industry is currently facing major changes in its environment (Lurquin 1996:6), resulting in a number of critical business issues, such as the high degree of regulatory influence, emerging customer and consumer power and increasing cost pressures.

\subsubsection{High degree of regulatory influence}

The pharmaceutical industry is among the most heavily regulated because of the potential for damage to the human body. Organizations using enterprize systems must ensure that the software supports lot traceability, formulation integrity and inventory recording, among other things. These standards are created and enforced on a national and/or regional basis. Noncompliance can lead to the withdrawal of licenses to manufacture a product. Regulatory agencies worldwide have been placing more and more emphasis on computer systems' validation over the past five years.

\subsubsection{Emerging customer and consumer power}

In the past, the pharmaceutical organization's main customers* were general practitioners (or GPs) who were responsible for the purchasing decisions, although there were certain products where the purchaser was a hospital or specialist. The possibility of generic and therapeutic substitution by a pharmacist, the growing power of medical aid, insurance organizations and prescribing committees and the awareness of patients themselves are now altering this. This change in the customers of the pharmaceutical manufacturers will have a major impact on the supply chains of pharmaceutical companies (Booth 1996:6). As a result, many pharmaceutical organizations have increasingly been using direct consumer advertisements to market their drugs to consumers. The intention is that they will ask their general practitioners or other medical service providers about a particular drug and this would lead to brand preference with customers and consumers.

\subsubsection{Increasing cost pressures}

In most countries, health care is changing. Managed care continues a strong growth in addition to all the issues associated with government-provided care. In many cases, this means that managed health care organizations are placing enormous pressure on pharmaceutical organizations to reduce costs. They are also increasingly considering generic substitutes and buying-group influence. 


\subsection{Context of the pharmaceutical organization}

The pharmaceutical organization in this research manufactures generic and OTC medication. The organization is a subsidiary of a multinational pharmaceutical organization, which manufactures a broad range of pharmaceutical products, including ethical pharmaceuticals.

The pharmaceutical organization used a distributor, which was jointly owned by 12 pharmaceutical manufacturing organizations, to warehouse and distribute finished goods in five national warehouses and handle all activities related to order entry. The distributor sold both directly to its customers (mostly hospitals, clinics, pharmacies and doctors in the private and public sector) and to wholesalers, who then sold to these and other customers. Customers were located nationally or internationally. While the distributor handled the majority of the sales, the manufacturer occasionally sold raw materials or exported materials directly to customers, due to the pricing of the distributor. This is depicted in Figure 3.

Figure 3 Flow of products from pharmaceutical manufacturer to the customer

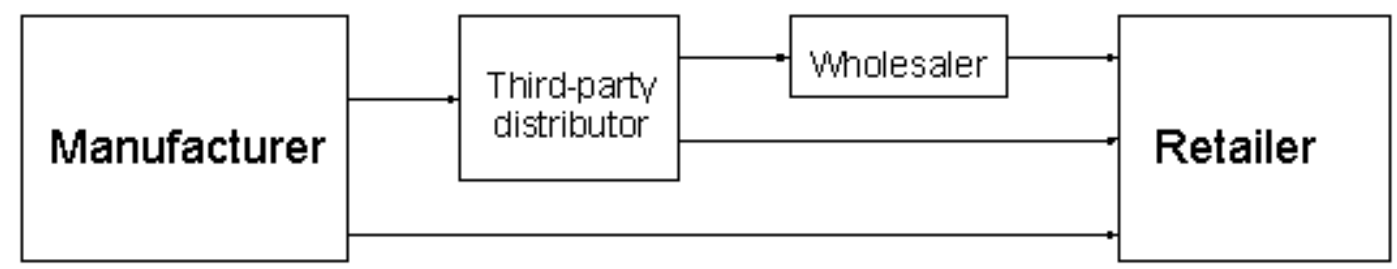

The distributor was responsible for:

- Warehousing finished goods

- Capturing of customer orders

- Performing physical distribution

- Producing invoices and goods received notes

- Maintaining master data for customers, together with pricing data.

The organization implemented several financial and manufacturing modules of an enterprize resource planning (ERP) software package. An Olap tool was used to provide reporting and analysis of sales data received from the distributor to the senior and middle management in the sales and marketing function. While this particular tool allowed for on-line analytical processing, it did not meet all user requirements since it did not, for example, integrate other data sources such as costing data, which allows for profitability to be analysed. In addition, the data structures were not appropriate for the data or for the query and analysis requirements of users, which resulted in users frequently requesting reports from the thirdparty distributor. This was costly and time consuming.

Apart from the Olap tool, other data sources included a magnitude of spreadsheets on a number of file servers in user directories.

The organization knew that it wanted to eventually build an enterprize-wide data warehouse. However, it was decided that sales and marketing were most urgently in need of information and most likely to deliver a 'quick win'. The organization intended to include other functional areas, namely finance, production planning and scheduling, as well as external market intelligence data in future. Therefore, a dependent sales and marketing data mart was the first in a series of interdependent data marts resulting in a distributed data warehouse.

\subsection{Sales and marketing data mart solution requirements}

\subsubsection{User community}

The user community for the sales and marketing data mart consisted of members of senior 
and middle management. Their positions together with a corresponding non-exhaustive list of the primary responsibilities of each position, which particularly require sales and marketing-related management information, are given in Table 6.

Table 6 Principal responsibilities by position in a pharmaceutical manufacturing organization

\begin{tabular}{|c|c|}
\hline Position & Principal responsibilities, including but not limited to: \\
\hline Managing director & - Responsible for full profit and loss \\
\hline $\begin{array}{l}\text { Financial and } \\
\text { operations director }\end{array}$ & $\begin{array}{l}\text { - Report and analyse financial results } \\
\text { - Design, develop and implement financial strategy } \\
\text { - Adequately maintain inventory levels together with } \\
\text { sales and marketing directors }\end{array}$ \\
\hline Marketing director & $\begin{array}{l}\text { - Evaluate market trends, reviewing competitor } \\
\text { information and business ranking data to develop } \\
\text { strategies to better the organization's position in the } \\
\text { marketplace }\end{array}$ \\
\hline Sales director & $\begin{array}{l}\text { - Deliver sales results to meet budgeted targets } \\
\text { - Establish pricing guidelines on a product-by-product } \\
\text { basis } \\
\text { - Use appropriate analysis techniques to identify business } \\
\text { problems and issues, including gap analysis on sales } \\
\text { performance, risk management and contingency } \\
\text { planning }\end{array}$ \\
\hline $\begin{array}{l}\text { New business } \\
\text { development } \\
\text { director }\end{array}$ & $\begin{array}{l}\text { - Plan and execute new business development strategy } \\
\text { for the firm } \\
\text { - Monitor success of new products in the marketplace } \\
\text { - Establish branded generic products in the marketplace }\end{array}$ \\
\hline $\begin{array}{l}\text { Marketing research } \\
\text { manager }\end{array}$ & $\begin{array}{l}\text { - Participate in the development of pricing and product } \\
\text { positioning strategies } \\
\text { - Maintain up-to-date forecast models, reflecting current } \\
\text { data and assumptions for the sales and operations } \\
\text { planning purposes } \\
\text { - Compile and analyse secondary marketing and sales } \\
\text { data }\end{array}$ \\
\hline $\begin{array}{l}\text { Regional sales } \\
\text { managers }\end{array}$ & $\begin{array}{l}\text { - Analyse regional market penetration and travel logistics } \\
\text { and implement programmes to achieve optimal territory } \\
\text { coverage } \\
\text { - Provide accurate forecasts to regional sales director of } \\
\text { predicted revenue levels }\end{array}$ \\
\hline $\begin{array}{l}\text { National account } \\
\text { managers }\end{array}$ & $\begin{array}{l}\text { - Meet and/or exceed sales goals for assigned region } \\
\text { - Manage the relationship with key suppliers }\end{array}$ \\
\hline
\end{tabular}

\subsubsection{Management information requirements}

Since the user community had been exposed to the functionality of data mart access tools, it was able to articulate its management information requirements in the form of the type of information to be available and the business questions to be answered by the system rather than particular reports. This is a more appropriate means of communicating requirements for a data mart project.

The data mart must be able to provide answers to the following categories of management information requirements: 
- Internally focused marketing information, such as sales, costs and marketing performance indicators

- Externally focused marketing information, such as industry trends and competitive intelligence

- Historical marketing information, such as sales, profitability and market trends

- Future-orientated marketing information, such as environmental scanning information

- Quantitative marketing information, such as costs, profitability and market share

- Qualitative, often subjective marketing information, such as buyer behaviour and competitor strategy information.

These business questions can be answered through specific management reports, which allow for user interaction.

\subsubsection{Data mart access tool requirements}

Based on the management information reporting requirements, requirements for the data mart access tool can be determined. These are detailed in Table 7.

Table 7 Representative sample of the requirements of the pharmaceutical manufacturer's data mart access tool

\begin{tabular}{|l|l|l|l|}
\hline $\begin{array}{c}\text { Management } \\
\text { information } \\
\text { requirement }\end{array}$ & \multicolumn{1}{|c|}{ Stage of use } & Nature & $\begin{array}{c}\text { Data mart access } \\
\text { tool }\end{array}$ \\
\hline $\begin{array}{l}\text { Sales related: } \\
\text { - Sales report } \\
\text { - Sales forecast }\end{array}$ & $\begin{array}{l}\text { Reporting } \\
\text { analysis }\end{array}$ & Deductive & $\begin{array}{l}\text { Query and reporting } \\
\text { Olap }\end{array}$ \\
\hline $\begin{array}{l}\text { Marketing related: } \\
\text { - Average selling } \\
\text { price (ASP) and } \\
\text { unit forecasts } \\
\text { - Promotions } \\
\text { - New business } \\
\text { development }\end{array}$ & $\begin{array}{l}\text { Reporting } \\
\text { analysis }\end{array}$ & Deductive & $\begin{array}{l}\text { Query and reporting } \\
\text { Olap }\end{array}$ \\
\hline $\begin{array}{l}\text { Inventory related: } \\
\text { - Stock on hand } \\
\text { - Back orders }\end{array}$ & Reporting & Deductive & Query and reporting \\
\hline $\begin{array}{l}\text { Profitability or } \\
\text { margin analysis }\end{array}$ & $\begin{array}{l}\text { Reporting } \\
\text { analysis }\end{array}$ & Deductive & $\begin{array}{l}\text { Query and reporting } \\
\text { Olap }\end{array}$ \\
\hline Rebates & Reporting & Deductive & Query and reporting \\
\hline Commissions & Reporting & Deductive & Query and reporting \\
\hline $\begin{array}{l}\text { Distribution related: } \\
\text { • Costs }\end{array}$ & $\begin{array}{l}\text { Reporting } \\
\text { Analysis }\end{array}$ & Deductive & $\begin{array}{l}\text { Query and reporting } \\
\text { Olap }\end{array}$ \\
\hline
\end{tabular}

\subsubsection{Sources of data}

Based on the management information requirements, the sources of data to be used to populate the data mart were determined. The internal sources of data used to populate the data mart were:

- Budget data

- Expenses data

- Costing data. 
The pharmaceutical manufacturer downloaded the following flat files (external data) from the distributor's operational systems:

1. Invoices issued on the previous day

2. Customer master data of additions and modifications

3. Inventory levels in the respective warehouses

4. Orders placed but not yet invoiced

5. Outstanding or backorders

6. Inventory transactions

7. Balancing report consisting of cumulative month-to-date balances.

Files 1, 2, 3, 4, and 5 were used to populate the data mart. The balancing report was used to ensure correct uploading of data into the database. The manufacturer wanted to capture additional data particular to its operations on both the customer and product master data, for example, sales representative responsibility. This required a custom-developed application. The volume of sales transactions was approximately 800 to 1000 transactions per day. The inventory transactions were omitted as inventory levels required monitoring only and did not require that inventory transactions be kept in any of the manufacturer's systems.

\subsubsection{Assessment of the use of the sales and marketing data mart}

An assessment of the sales and marketing data mart after completion of the implementation as a management information delivery mechanism indicated that it had a significant impact on the manufacturing organization. Information that was previously too difficult to derive because of multiple source systems was now available on the users' desktops. Information flowed up and down the organization much faster, increasing the speed and quality of key marketing and sales decisions. Most importantly, the organization saw a significant improvement in the accuracy of its sales forecasts. One comment was that the previous system overemphasize quantitative data over qualitative data.

The increased visibility of data through direct access using the data mart access tools exposed the low quality of the data received from the third-party distributor. Initially, this discrepancy was ascribed to the new system. However, once users were shown the source files from which the data were received, it became clear that the service provided by the third-party distributor with regard to data capture and provision was lacking. This is a frequent result of data warehouse or mart implementations (Kimball and Merz 2000). The results of analysis undertaken, using the data mart, were therefore viewed with increased credibility given the ability of the data mart to process vast and complex data with speed and in detail.

\section{Comparative analysis}

In the preceding sections, the use of sales and marketing data marts as a management information delivery mechanism in manufacturing organizations when the data source is outside of the organizations' boundaries, namely with third-party distributors, was shown through two case studies.

\subsection{User community}

The target user communities for the respective organizations were senior and middle management. A comparison between the BCP and pharmaceutical manufacturing organizations in terms of positions requiring access to the sales and marketing data mart by management level is listed in Table 8. 
The user community of the sales and marketing data marts in both organizations was largely similar with matches in five of the seven positions affected. The differences can be attributed to the different industry characteristics of the two organizations, the pharmaceutical manufacturer requiring significantly more sophisticated market research and competitive intelligence. The use of the data mart by the managing director was a personal preference to have direct access to data rather than indirect access through directors reporting to him or her, which is a reflection of the management style and organizational culture.

Table 8 Comparison of user community for respective sales and marketing data marts by management level

\begin{tabular}{|c|c|c|c|}
\hline Management level & $\begin{array}{l}\text { Case study 1: } \\
\text { Branded } \\
\text { consumer } \\
\text { products (BCP) } \\
\end{array}$ & $\begin{array}{l}\text { Case Study 2: } \\
\text { Pharmaceutical }\end{array}$ & Match? \\
\hline \multirow[t]{4}{*}{ Senior } & - & Managing director & $x$ \\
\hline & Financial director & Financial director & $\checkmark$ \\
\hline & \multirow{2}{*}{$\begin{array}{l}\text { Sales and } \\
\text { marketing director }\end{array}$} & Sales director & $\checkmark$ \\
\hline & & Marketing director & $\checkmark$ \\
\hline \multirow[t]{3}{*}{ Middle } & $\begin{array}{l}\text { Regional sales } \\
\text { managers }\end{array}$ & $\begin{array}{l}\text { Regional sales } \\
\text { managers }\end{array}$ & $\checkmark$ \\
\hline & $\begin{array}{l}\text { National account } \\
\text { managers }\end{array}$ & $\begin{array}{l}\text { National account } \\
\text { managers }\end{array}$ & $\checkmark$ \\
\hline & - & $\begin{array}{l}\text { Marketing research } \\
\text { manager }\end{array}$ & $x$ \\
\hline
\end{tabular}

\subsection{Management information requirements}

Although the management information requirements were similar in nature, they differed with regard to the extent of data required to fulfil the information needs, as well as the method used to specify requirements, namely replicating existing reports versus answering a variety of business questions. Furthermore, the pharmaceutical organization used the data mart not only to deliver sales and marketing reports, but also some operational reports, namely for commissions and calculations. It can be concluded that the pharmaceutical organization was somewhat more sophisticated than the BCP organization with regard to management information requirements.

\subsection{Data mart access tool requirements}

Both organizations developed independent data marts with a view to developing a distributed data warehouse by means of an interdependent data mart. However, the access tool requirements of these data marts differed somewhat with regard to the type of data mart access required. The BCP organization only required query and reporting while the pharmaceutical organization required both query and reporting, and Olap. Therefore, one organization was still at the first stage of use, namely reporting, while the other progressed to analysis. Neither organization had yet explored the possibility of the predictive use of data through data mining. The organizations' progress is indicated in Table 9.

Table 9 Organizations' progress on the stages of data mart use

\begin{tabular}{|l|l|l|l|}
\hline Stage of use & Reporting & Analysis & Prediction \\
\hline Class of access tool & $\begin{array}{l}\text { Query and } \\
\text { reporting }\end{array}$ & Olap & Data mining \\
\hline
\end{tabular}




\begin{tabular}{|l|l|l|l|} 
Categories & Deductive & Deductive & Inductive \\
\hline $\begin{array}{l}\text { Case study 1: } \\
\text { Branded } \\
\text { consumer } \\
\text { products } \\
\text { organization }\end{array}$ & & & \\
\hline $\begin{array}{l}\text { Case study 2: } \\
\text { Pharmaceutical } \\
\text { organization }\end{array}$ & & & \\
\hline
\end{tabular}

\begin{tabular}{|l|l|}
\hline \multicolumn{2}{|l|}{ Legend } \\
\hline & Implemented \\
\hline & Not yet implemented \\
\hline
\end{tabular}

\subsection{Sources of data}

Data sourced externally, that is, particular to either one of the organizations, were:

- Backorders

- Orders placed but not yet invoiced

- Product master data.

The reasons for the differences between the organizations with regard to externally sourced data were:

- Order data were held by the BCP manufacturer in one instance and by the pharmaceutical organization's distributor in another.

- Although both manufacturers maintained product master data, the BCP manufacturer's distributor maintained this data and the manufacturer decided to use the external source for cross-reference purposes.

In both instances, small volumes of transactions were handled on a daily basis resulting in a relatively small database size, although the transactions were complex in nature and therefore required complex processing.

\subsection{Assessment of the use of the data marts}

The benefits derived from the implementation of the data marts in each of the case study organizations are listed in Table 10.

Table 10 Benefits derived from the implementation of data marts in case study organizations

\begin{tabular}{|l|l|l|l|}
\hline Nature of benefit & Derived benefit & $\begin{array}{l}\text { Case Study 1: } \\
\text { Branded } \\
\text { consumer } \\
\text { products } \\
\text { organization }\end{array}$ & $\begin{array}{l}\text { Case Study 2: } \\
\text { Pharmaceutical } \\
\text { organization }\end{array}$ \\
\hline Tangible & $\begin{array}{l}\text { Sales improved } \\
\text { through improved } \\
\text { targeted trade }\end{array}$ & $\checkmark$ & $\checkmark$ \\
\hline
\end{tabular}




\begin{tabular}{|c|c|c|c|}
\hline & $\begin{array}{l}\text { marketing and } \\
\text { monitoring of the } \\
\text { outcome }\end{array}$ & & \\
\hline & \begin{tabular}{|l} 
Improved \\
forecasting \\
accuracy
\end{tabular} & $\checkmark$ & $\checkmark$ \\
\hline & \begin{tabular}{|l} 
Sales \\
representatives \\
were better \\
prepared for sales \\
visits \\
\end{tabular} & $\checkmark$ & $x$ \\
\hline & $\begin{array}{l}\text { Exposed the } \\
\text { shortcomings of } \\
\text { underlying data } \\
\text { quality }\end{array}$ & $x$ & $\checkmark$ \\
\hline & Reduced paperwork & $x$ & $\checkmark$ \\
\hline & $\begin{array}{l}\text { Improved customer } \\
\text { information }\end{array}$ & $x$ & $\checkmark$ \\
\hline & \begin{tabular}{|l} 
Reduced \\
expenditure
\end{tabular} & $x$ & $\checkmark$ \\
\hline Intangible & $\begin{array}{l}\text { Direct user access } \\
\text { to a single } \\
\text { integrated source of } \\
\text { management } \\
\text { information } \\
\text { through a data mart } \\
\text { access tool } \\
\end{array}$ & $\checkmark$ & $\checkmark$ \\
\hline & $\begin{array}{l}\text { Improved } \\
\text { information flow } \\
\text { and communication } \\
\text { with a perceived } \\
\text { positive impact on } \\
\text { decision making } \\
\end{array}$ & $\checkmark$ & $\checkmark$ \\
\hline & $\begin{array}{l}\text { Organizational time } \\
\text { saving }\end{array}$ & $x$ & $\checkmark$ \\
\hline
\end{tabular}

Both organizations derived significant benefits from the implementation of the sales and marketing data marts. A significant number of benefits derived were similar between the two organizations, although it appeared as if the pharmaceutical organization received more benefits than the BCP organization, in particular with regard to tangible benefits.

In summary, the comparative analysis of the sales and marketing data mart solutions as in the two organizations discussed in the previous chapter is listed in Table 11.

Table 11 Summary of comparative analysis between case study data marts

\begin{tabular}{|l|l|}
\hline User community & $\begin{array}{l}\text { Mostly similar, but differences were due to a difference in } \\
\text { the organizational structure as well as the culture in terms } \\
\text { of information use and the industries in which the } \\
\text { organizations operate }\end{array}$ \\
\hline & Similar in nature, but differed with regard to extent of data
\end{tabular}




\begin{tabular}{|l|l|}
$\begin{array}{l}\text { Management } \\
\text { information } \\
\text { requirements }\end{array}$ & $\begin{array}{l}\text { required to fulfil information needs and the methods used } \\
\text { to specify requirements - the pharmaceutical organization } \\
\text { was somewhat more sophisticated in its expression of } \\
\text { management information requirements }\end{array}$ \\
\hline $\begin{array}{l}\text { Data mart access tool } \\
\text { requirements }\end{array}$ & $\begin{array}{l}\text { Different levels of progression with regard to the nature of } \\
\text { use that was seen as different stages of development } \\
\text { within the respective organizations }\end{array}$ \\
\hline $\begin{array}{l}\text { Nature and sources of } \\
\text { data used to populate } \\
\text { the data mart }\end{array}$ & $\begin{array}{l}\text { Largely similar in volume and complexity, with } \\
\text { differences due to where orders were placed and where } \\
\text { product master data were held }\end{array}$ \\
\hline $\begin{array}{l}\text { Assessment of the data } \\
\text { mart implementations }\end{array}$ & $\begin{array}{l}\text { Similar types of benefits at the two organizations, } \\
\text { although it seemed that the pharmaceutical organization } \\
\text { received more benefits relative to the BCP organization } \\
\text { due to more sophisticated management information usage }\end{array}$ \\
\hline
\end{tabular}

\section{Conclusion}

Given the summary of the comparative analysis of sales and marketing data marts as management information delivery mechanisms in manufacturing organizations in Table 11, differences can be attributed to organizational culture and structure, levels of information technology sophistication and the level of information usage. As an overall result, the benefits derived from the data mart implementations also differed. The hypothesis, that there is no significant difference in the use of sales and marketing data marts as management information delivery mechanisms in manufacturing organizations in different industries, particularly for pharmaceutical and branded consumer products, is therefore rejected. There are significant differences that can be ascribed to the industry variable within the general manufacturing industry. Furthermore, the required level of information usage can be seen as a variable co-dependent on the industry since different industries require different levels of information usage.

\section{Acknowledgements}

The financial assistance of the National Research Foundation (NRF) towards this research is hereby acknowledged. Opinions expressed and conclusions arrived at are those of the authors and are not necessarily those of the National Research Foundation.

\section{References}

3COM. 2001. Data warehousing solutions. High-availability, high-performance networks support superior business decisions. In Data Warehousing: the ultimate guide to building corporate business intelligence. Ed. B.V. Wiesbaden. Vieweg: SCN Education.

Berson, A. and Smith, S.J. 1997. Data warehousing, data mining, and OLAP. New York: McGraw-Hill.

Booth, R. 1996. The role of supply-chain re-engineering in the pharmaceutical industry. Logistics Information Management 9(3):4-10. 
Brooke, K. and Mactavish, D. 2001. Forecasting the future - planning for tomorrow.

[Online]. Available WWW: http://www.dmreview.com/editorial/dmreview/print_action.cfm?

EdID=3896 (Accessed 23 November 2002).

Davenport, T. H., Harris, J. G. and Kohli, A. K. 2001. How do they know their customers so well? MIT Sloan Management Review (Winter 2001):63-73

Gray, P. and Watson, H.J. 1998. Decision support in the data warehouse. New Jersey: Prentice-Hall.

Kimball, R. and Merz, R. 2000. The data Web house toolkit: building the Web-enabled data warehouse. New York: John Wiley.

Lurquin, M.G. 1996. Streamlining the supply chain in the pharmaceuticals industry. Logistics Information Management 9(6):6-10.

Poe, V., Klauer, P. and Brobst, S. 1998. Building a data warehouse for decision support. Second edition. New Jersey: Prentice-Hall.

SSA. Pharmaceutical and speciality chemicals. [Online]. Available WWW: http://www.ssagt.com/product/industry/industry.htm (Accessed 15 February 2000).

Swift, R. 2000. The stages of growth for CRM and data warehousing. [Online]. Available WWW: http://www.dmreview.com/master.cfm?NavID=55andEdID=2632 (Accessed 13 September 2001).

Tanler, R. 1997. The intranet data warehouse: tools and techniques for building an intranetenabled data warehouse. New York: John Wiley.

Vishwanath, V. and Mark, J. 1997. Your brand's best strategy. Harvard Business Review (May-June):123-129.

Vivier, F. 2001. The impact of B2B technology on the products industry. Andersen products, retail and services workshop. Johannesburg: Gordon Institute of Business.

\section{Disclaimer}

Articles published in SAJIM are the opinions of the authors and do not necessarily reflect the opinion of the Editor, Board, Publisher, Webmaster or the Rand Afrikaans University. The user hereby waives any claim he/she/they may have or acquire against the publisher, its suppliers, licensees and sub licensees and indemnifies all said persons from any claims, lawsuits, proceedings, costs, special, incidental, consequential or indirect damages, including damages for loss of profits, loss of business or downtime arising out of or relating to the user's use of the Website. 
ISSN 1560-683X

Published by InterWord Communications for the Centre for Research in Web-based Applications, Rand Afrikaans University 